\title{
Development Cooperation in the Context of Contested Global Governance
}

\author{
Sachin Chaturvedi, Heiner Janus, Stephan Klingebiel, \\ Li Xiaoyun, André de Mello e Souza, Elizabeth Sidiropoulos, \\ and Dorothea Webrmann
}

\subsection{INTRODUCTION}

The 2030 Agenda for Sustainable Development has successfully set a normative framework that defines development as a universal aspiration for inclusiveness and sustainability. Furthermore, this global agreement contains concrete and measurable goals, targets, and indicators that can be used to hold governments and non-governmental actors accountable for achieving sustainable

S. Chaturvedi $(\varangle)$

Research and Information System for Developing Countries (RIS), New Delhi, India e-mail: sachin@ris.org.in

H. Janus · S. Klingebiel · D. Wehrmann

German Development Institute / Deutsches Institut für Entwicklungspolitik (DIE), Bonn, Germany

e-mail: heiner.janus@die-gdi.de

S. Klingebiel

e-mail: stephan.klingebiel@die-gdi.de

D. Wehrmann

e-mail: dorothea.wehrmann@die-gdi.de

X. $\mathrm{Li}$

China Agricultural University, Beijing, China

e-mail: xiaoyun@cau.edu.cn 
development (Fukuda-Parr and McNeill 2019). Particularly in the field of development cooperation, the 2030 Agenda has become the most prominent reference framework for policy-making and, even beyond the field of development cooperation, the 2030 Agenda is seen as enhancing international cooperation geared towards the global common good (Messner and Scholz 2018).

Yet, the negotiation process among United Nations (UN) member states was politicised (Kapto 2019) and the agenda has been characterised by power struggles (Burke and Rürup 2019) and unresolved contestations (McNeill 2019). Given the mostly incoherent and fragmented landscape of global cooperation, particularly in the field of development cooperation, it is uncertain whether the Sustainable Development Goals (SDGs) will be achieved. Although we see an opportunity for development cooperation actors to find better ways of coordinating across what we call "sites of contested cooperation" (Mello e Souza 2021; Janus and Tang 2021, Chapter 10), we observe the lack of a comprehensive assessment on the current state of different approaches to development cooperation and their potential contribution to the implementation of the 2030 Agenda (Fiddian-Qasmiyeh and Daley 2019a; Kragelund 2019). Against this backdrop, we ask: How can different narratives and norms in development cooperation be reconciled to achieve the 2030 Agenda? This central question guides the handbook.

In the handbook, we propose to answer this question in three main steps. First, we argue that we need a more detailed overview of the narratives and norms shaping distinct approaches in the policy field of development cooperation. Second, we strive for a better understanding of persisting and new institutional sites of contestation. Third, we explore how international governance structures can better address contestation and improve cooperation.

In recent years, development cooperation has been in search of a new narrative for underlying motives and rationales. The 2030 Agenda provides a comprehensive global framework that represents a broader consensus than previous frameworks (e.g. Millennium Declaration and the Millennium Development Goals, MDGs). However, a significant weakening of multilateral problem-solving approaches is challenging its implementation. The rise of nationalistic populism and "my country first" movements-not just in the

A. de Mello e Souza

Institute for Applied Economic Research, Rio de Janeiro, Brazil

e-mail: andre.souza@ipea.gov.br

E. Sidiropoulos

Wits University, South African Institute of International Affairs, Johannesburg,

South Africa

e-mail: elizabeth.sidiropoulos@wits.ac.za 
United States, the UK, and Central and Eastern Europe, but also across Asia and other regions-has strengthened anti-globalisation and pro-national interest narratives. This trend has also impacted domestic development agendas (Roberts 2018). Globalisation challenges, such as violent conflicts, increasing migration and numbers of refugees, as well as climate change as a global challenge, have turned discourses on development cooperation away from development-oriented motives towards the strategic interests of development cooperation providers, such as expanding their own political and economic opportunities (Mawdsley et al. 2018). Countries leverage foreign aid to influence UN decision-making processes, and newly designed migration compacts between the European Union and African partners serve as additional examples in this regard.

Along with changing narratives, development cooperation has been subject to increased norm competition. The norms and standards for implementing development interventions are more diversified with a changing institutional landscape of development cooperation (Bhattacharya and Llanos 2016; Fejerskov et al. 2017; Gray and Gills 2018). For many decades, the Organisation for Economic Co-operation and Development's (OECD) Development Assistance Committee (DAC) held the de facto monopoly in defining norms for development cooperation. As a reaction to the growing importance of SouthSouth cooperation (SSC) providers, the DAC has revised its concept of official development assistance (ODA) and proposed an additional measurement for covering “Total Official Support for Sustainable Development”. Meanwhile, providers of SSC and private actors have introduced alternative (and complementary) norms and standards that better reflect their requirements and values, such as "mutual benefits" and "horizontality" (Fourie et al. 2019; Hansen and Wethal 2015). In addition, emerging economies have created new international institutions such as the New Development Bank (NDB) and the Asian Infrastructure Investment Bank (AIIB) (Wang 2019). We are therefore witnessing an increasingly fragmented landscape of institutions, norms, and standards for implementing development interventions.

Norm competition also extends to measuring the quality of development cooperation at the level of providers, beneficiaries, and individual projects, as exemplified by different conceptual and analytical frameworks for, among other things, SSC (Besharati et al. 2017). Whereas previous policy debates focussed on "aid effectiveness" principles and project evaluation guidelines defined by the OECD-DAC, the current landscape has become more fragmented (Klingebiel et al. 2016). There is no universal framework for measuring the quality, impact, or results of development cooperation, and the SDGs have opened up new opportunities for different providers of development cooperation to present their respective strengths (Uchenna and Simplice 2018). Most development actors can easily align themselves with the SDGs because the 2030 Agenda does not provide specific guidance on defining the quality of development cooperation (Pérez-Pineda and Wehrmann 2021, Chapter 30; Rudolph 2017). At the project level, a wealth of new research, methods, and data has increased our knowledge of how development cooperation across the world can work. Yet, establishing universal standards and 
comparability across development interventions, as well as data availability and quality, remains a challenge (Ali 2021, Chapter 13; Keijzer 2016; Organisation for Economic Co-operation and Development 2018), also due to the inherently political nature of the different approaches being pursued (Fourie et al. 2019).

Apart from narratives and norms, we need a better understanding of persisting and new sites of contestation in development cooperation. These sites can include international and multilateral organisations, multi-stakeholder partnerships, bilateral and multilateral cooperation, or other development cooperation-related platforms. From a global governance perspective, the SDGs provide an inclusive multilateral umbrella that encompasses a range of these sites of contestation where various actors can engage across the policy field of development cooperation. Such a loose umbrella is useful because it provides an overarching supra-architecture for all types of cooperation. A major limitation, however, is that the SDG framework does not offer guidance on how different platforms can coordinate their contributions towards achieving the development goals in an integrated and holistic manner across local, national, regional, and international levels, as well as across all dimensions of sustainable development (Chan et al. 2021, Chapter 2; Kharas and Rogerson 2017). Moreover, the consensus reached on the SDGs is continually being contested due to changing political dynamics. As the rise of nationalist policies illustrates, international actors can quickly switch from supporting to undermining multilateralism.

Against this backdrop, we provide an overview of existing sites of contestation and newly emerging sites of contestation. There are several existing sites of contestation in the policy field of development cooperation. Most prominently, the UN Development Cooperation Forum (UN DCF) and the Global Partnership for Effective Development Co-operation (GPEDC) have worked alongside each other. The OECD and UN Development Programme jointly host the GPEDC. However, the partnership is still primarily associated with the 30 member countries of the OECD's Development Assistance Committee. In contrast, the UN DCF has a universal membership of the 193 UN member states. In recent years, the number of exchanges between both platforms has increased, but neither platform has become universally accepted as being effective for norm- and standard-setting in development cooperation. In addition, neither platform provides tangible inputs to the Financing for Development Forum of the UN, the official review mechanism of SDG 17, or the High-level Political Forum-the principal institutional platform for reviewing progress towards the SDGs. Other sites of contestation include, for instance, club governance formats such as the G20 development working group, the BRICS group (Brazil, Russia, India, China, and South Africa) (Lauria and Fumagalli 2019), the IBSA group (India, Brazil, and South Africa), and MIKTA, an informal grouping composed of Mexico, Indonesia, Korea, Turkey, and Australia formed in the margins of the UN General Assembly in 2013. 
Since the 2030 Agenda and SDG negotiations were started in 2013, new sites of contestation have emerged in development cooperation. Most prominently, new development banks have been founded by emerging countries, for example, the BRICS's NDB and the AIIB. These banks were established partly because emerging countries did not see their interests being adequately represented and also due to their distrust of traditional global governance institutions, in particular the Bretton Woods Institutions (Wang 2015). Hence, the creation of new development banks is an example of counter-institutionalisation. Other examples for new sites of contestation include regional initiatives such as the Belt and Road Initiative and the Silk Road Fund by China, the "New Marshall Plan" for Africa, and the Asia-Africa Growth Corridor launched by India and Japan. These new sites of contestation are not explicitly geared towards the policy field of development cooperationthey all touch on trade and investment-but they do have fundamental impacts on how development cooperation is changing.

Apart from mapping the various sites of contestation in development cooperation, there is a need to explore how existing governance structures can be improved to deal with contestation and avoid gridlock (Hale et al. 2013). Achieving the SDGs will also depend on how successful development cooperation actors can be in advancing different types of cooperation and finding constructive ways of addressing contested responsibilities. Within the SDG framework, we find tentative examples of how this process might unfold. These examples fall into two categories: existing forms of cooperation that turn towards taking on greater responsibilities, and new forms of cooperation that are started because of the SDGs.

As examples for the first category of existing types of cooperation and governance mechanisms, we consider ODA providers who have taken on a holistic development cooperation perspective. Traditional ODA provision is geared towards tackling domestic problems in poorer countries in the form of North-South cooperation, including (the still relevant) challenge of poverty reduction. More recent debates on ODA, in addition, acknowledge universality and the role that ODA can play in promoting developmental policies in donor countries, as well as the role of ODA in providing global public goods (Janus et al. 2015; Kaul 2016; Paulo and Klingebiel 2016). ${ }^{\text {l }}$ The traditional understanding of SSC, shaped by the Buenos Aires Plan of Action of 1978, focussed mostly on the provision of technical assistance, whereas new directions for SSC focus on analysing the expansion of the development finance, trade, and investment elements of SSC and their developmental effects (Fiddian-Qasmiyeh and Daley 2019b; Kragelund 2019; Mawdsley 2019; Mawdsley et al. 2019).

Examples for the second category of new types of cooperation and governance mechanisms can be found in the emergence of North-North and SouthNorth cooperation as well as in the growing number and diversity of multiactor partnerships (Beisheim and Liese 2014; Wehrmann 2018). Furthermore, there are reciprocal learning formats in which knowledge communities or 
communities of practice self-organise around sustainable development challenges. For instance, countries across all income groups (low-, middle-, and high-income) have formed alliances to promote voluntary sustainability standards. Another example is the Group of Friends of the Voluntary National Reviews, which advocates for rigorous reporting on the SDGs. Providing a better understanding of how new cooperation formats have emerged and which specific mechanisms have enabled existing cooperation formats to take on more responsibility is another main contribution of this book.

Across the individual chapters in this handbook, we bring all three components together-(i) mapping narratives and norms, (ii) identifying and investigating sites of contestation, and (iii) reflecting on better governance structures for SDG cooperation. Each chapter provides a unique perspective on these conceptual and practical challenges for development cooperation and adds to the overall tapestry of knowledge on the complex policy field we call development cooperation, in particular towards better understanding and addressing contested cooperation for achieving the SDGs.

\subsection{COORDINATION AND RESPONSIBILITIES: The Twin Challenges of the SDGs}

The guiding question of this handbook ("How can different narratives and norms in development cooperation be reconciled to achieve the 2030 Agenda?") builds on two challenges that we consider central for the implementation of the 2030 Agenda and that we understand as the twin challenges of the SDGs: How can different SDG-related policies be coordinated? And how can responsibilities be divided in a just manner?

Achieving the SDGs requires coordinating policies across different policy fields at different global levels. The coordination challenges in this context are grouped into three categories: interdependencies of policies, collective action problems, and disconnected national and global policy-making.

First, the 17 goals, 169 targets, and 232 indicators of the SDG framework form a complex web of interdependencies with potential synergies and trade-offs across different policies (Barbier and Burgess 2019). Research has produced the first conceptual tools for mapping these interconnections (Nilsson et al. 2016), including network analysis (Le Blanc 2015), but countries have not yet applied these tools to inform their decision-making. Instead, "there is a considerable risk that countries will adopt arbitrary or politically salient approaches to prioritisation and/or pursue the same 'siloed' approaches that have met with limited success in the past" (Allen et al. 2018, p. 422). The skills of governments to organise, manage, lead, and scale cross-sector cooperation are traditionally limited (Florini 2018). This problem is compounded by the extremely broad scope of the SDG agenda, which includes virtually all aspects of development. The agenda brings together a plethora of 
distinct actors and encourages the formation of new partnerships in development cooperation, but at the same time it allows stakeholders to justify and legitimise any policy or set of policies as contributing to such an agenda.

Second, due to the numerous collective action problems contained in the SDGs, multiple actors with divergent and often conflicting interests need to cooperate across multiple sectors and jurisdictional levels (Bowen et al. 2017). This coordination challenge has been conceptualised in different ways across economics (public choice theory, transaction costs, game theory) and political science (analysing voting or environmental policies, for instance). The core of collective action problems is that individual actors usually do not act in the common interest (Olson 2009), even if they will benefit, leading to coordination failures and suboptimal outcomes, in particular, underproviding global public goods (Bodenstein et al. 2017). In this way, the provision of global public goods such as a stable climate, safety from communicable diseases, global security, and financial stability mirrors collective action problems to be addressed when envisioning the implementation of the SDGs (Kaul 2018).

Third, national and global level policy-making are often disconnected. To date, national plans for achieving the SDGs appear to be shaped by path dependencies, rather than by systematic analyses of interlinkages between SDGs (Breuer et al. 2019; Tosun and Leininger 2017) and across national and global levels. Most SDG indicators measure progress at the national level, and less than 30 per cent of indicators measure a "transboundary" effect (Mitchell 2021, Chapter 11). Richer countries provide bilateral support to developing countries for achieving the SDGs, but global- and regional-level discussions on collective action as well as debates on domestic development issues in richer countries are largely neglected. Finally, multi-stakeholder approaches that cut across local, national, and cross-border levels are still developing and are contested (Wehrmann 2018).

In addition to these coordination challenges, the SDGs mask underlying contested responsibilities. Even though the SDGs are universal, it has not been specified how different actors should share responsibilities for implementing the SDGs. SDG 17, on the means of verification, addresses issues such as finance, trade, and technology, but it mostly reaffirms existing commitments. The goal promotes partnerships, including public-private and civil society partnerships, but it does not provide concrete guidance for how to establish these partnerships. From a critical perspective, SDG 17 reflects strong moral ambitions-similar to MDG 8 on the global partnership-but elicits weak normative commitments, leading to a situation of voluntarism in cooperation (Cooper and French 2018). Such voluntarism and self-organisation may again spur goal incoherence (Chan et al. 2021, Chapter 2).

According to Bexell and Jönsson (2017), responsibilities can further be broken down into three different types: cause, obligation, and accountability. The causes of responsibility remain largely hidden in the SDG documents, as questions on how power relations and historical circumstances determine 
current responsibilities are not addressed (Bexell and Jönsson 2017). Responsibility in terms of obligation is seemingly boundless, leading to countless goal conflicts and exacerbating the goal conflicts identified above. Crucially, the SDGs do not clarify how diverse needs-particularly those of low-income countries-will be met and how rich countries will be held responsible by SDG 17 to leverage their wealth and influence towards global sustainable development. Responsibility in the sense of accountability is largely based on voluntarism, and even seemingly objective technical discussions on numbers, indicators, and data are the product of power relations and unresolved contestation (Fukuda-Parr and McNeill 2019). Overall, the SDG framework, therefore, did not make progress towards defining what "common but differentiated responsibilities" (Pauw et al. 2015) mean in practice, but instead gave rise to open and hidden forms of contestation at all levels of SDG implementation.

We argue that these twin challenges of the SDGs-unresolved coordination challenges and contested responsibilities - will hinder the achievement of the 2030 Agenda. Making progress towards achieving the SDGs thus requires that governmental and non-governmental actors cooperate more and find constructive ways of addressing these twin challenges. Although these two challenges apply to the overall SDG framework and potentially all policy fields related to the SDGs, we specifically focus on the policy field of development cooperation.

\subsection{The Policy Field of Development Cooperation}

The policy field of development cooperation is central for addressing these twin challenges of the SDGs for three main reasons. First, development cooperation actors were critical drivers of the 2030 Agenda and have always been closely linked to development debates in the UN. Second, development cooperation is functionally geared towards solving coordination problems through different forms of cooperation, either bilaterally or multilaterally, by facilitating dialogue and aligning ideas and interests. Third, development cooperation and policies in this field have historically dealt with contested responsibilities-from its origins in colonial history to reconstruction efforts after the Second World War, and from different alliances during the Cold War to discussions on global responsibilities today.

From a research perspective, we understand development cooperation as an organisational field (DiMaggio and Powell 1983; Scott 2013). Fields can be described as having three features: "a constitutional object binding the different organizations together, power relations shaping interaction between the different organizations in the field, and emerging rules and principles that organizations are expected to adhere to in order to be considered legitimate" (Fejerskov 2016, p. 5). For the book, we understand development cooperation broadly as an organisational field encompassing all actors that proclaim 
contributions to development cooperation. Individual chapters of this handbook, however, will apply specific definitions of different types of development cooperation based on the respective author's understanding.

Broadly defined, development cooperation, therefore, includes ODA providers, SSC providers, developing countries, and non-governmental actors (including civil society, philanthropy, and businesses). Similarly, Fejerskov et al. (2017) list states, including new global powers, industrialising countries, and post-socialist states; and non-state actors, which include private foundations, celebrity organisations, religious organisations, corporations, and social enterprises, as well as novel forms of grassroots or do-it-yourself development endeavours. Listing these actors in a joint category, however, is contested because each actor-whether it is a government from the North or the South, or a private actor-has its own definition of development cooperation, which does not necessarily correspond with other competing definitions (Fourie et al. 2019; Kragelund 2019).

The problem with broad definitions of development cooperation, however, as Mthembu (2018) points out, is that they cease to have any real meaning when just about any economic transaction between different actors can be seen as development cooperation. Hence, researchers have proposed more specific definitions that are centred on the overarching objective of development cooperation. Alonso and Glennie (2015) suggest that development cooperation needs to: (i) specifically intend to support development, (ii) operate through actions that would not be promoted (or at least not in the same way) by the market alone, (iii) differentiate in favour of developing countries, particularly the poorest, in order to broaden their opportunities for progress, and (iv) be based on cooperative relationships that try to enhance developing-country ownership. Mitchell (2021, Chapter 11) alternatively proposes to define development cooperation as "a country's policies, and how these affect the current and future welfare and growth of other countries' people and economies". Finally, Mthembu (2018) argues that development cooperation from Southern powers should be defined as official transfers of money, goods, and services (that are concessional in nature) to developing countries specifically for their economic development and welfare.

Even with these mores specific definitions of development cooperation, we claim that measurability and comparability across different types of development cooperation remain a challenge (see Part III of handbook on measurements of development cooperation). Although measuring financial components of development cooperation can be straightforward, the measurement of technical cooperation and policy spillovers between countries of contributions towards global public goods are more challenging. Kaul (2018) provides an overview of how to define global public goods and how to conceptualise global public policy that provides global public goods. She notes that, so far, there exists no fully-fledged global public policy, neither on the theoretical nor practical level, except for some limited policy innovations. Nevertheless, policies directed towards the global common good are needed 
not only for the implementation of the 2030 Agenda but also, as Messner and Scholz highlight (2018), to stabilise globalisation and to achieve sustainable human development for most people.

Moreover, in the field of development cooperation, we observe simultaneous contestation and cooperation in an ongoing dynamic process: In recent years, development cooperation has undergone fundamental and dynamic changes. These changes have been spurred by internal and contextual factors, such as the financial crisis in $2007 / 2008$, the rise of the digital economy, and the alignment of development goals with climate goals (TWI2050The World in 2050 [2018]; United Nations Department of Economic and Social Affairs 2018; World Bank 2018). ${ }^{2}$ In this context, a key trend affecting development cooperation has been the increasing global role of emerging economies and the disruption of established formats of cooperation (Chaturvedi et al. 2012; Zürn 2018b).

The growing contributions of SSC are often analysed alongside ODA, as defined by members of the OECD's DAC (Bergamaschi et al. 2017; Mawdsley et al. 2019). Others describe development cooperation between actors of the South in terms of a "new development compact" built on the principles of mutual gain, non-interference, and collective growth opportunities, and characterised by the absence of conditionalities (Chaturvedi 2016). According to a definition provided by IBSA, SSC is based on principles of "respect for national sovereignty; national ownership and independence; equality; non-conditionality; non-interference in domestic affairs; and mutual benefit"; IBSA partners claim that "SSC is completely different from the North-South/donor-donee cooperation, and that ODA templates are not a good basis for SSC" (Government of India 2018). However, common principles for effectiveness, differentiated assessment approaches, and the corresponding data for evaluation are still missing, limiting potentials for comparisons and knowledge transfers (Ali 2021, Chapter 13; Bhattacharya et al. 2021, Chapter 14). Others argue that such definitions and propositions on how the South should be analysed or mobilised would be "antithetical to the very foundations of the debates we and our contributors build upon in our respective modes of research and action" (Fiddian-Qasmiyeh and Daley 2019a, pp. 3-4).

From a global governance perspective, ${ }^{3}$ there has been a more extensive variety of narratives and norms put forward by an increasing number of heterogeneous actors in development cooperation (Mawdsley et al. 2019). Also, beyond the field of development cooperation, scholars suggest that global politics are embedded in normative and institutional structures that are dominated by hierarchies and power inequalities, and therefore inherently lead to contestation, resistance, and distributional struggles (Morse and Keohane 2014; Zürn 2018a). In institutions (and partnerships), for example, norms and standards guiding cooperation are the result of negotiation processes that are determined by organisational contexts such as organisational structures, practices, and departmental and individual relationships (Tjosvold 1984). These negotiation processes among states and non-governmental actors within existing fora and in new fora are what we understand as sites of contested 
cooperation. These sites of contested cooperation also determine how partnerships (and institutions) collaborate to achieve the 2030 Agenda, how their distinct purposes may relate to and build on each other, and ultimately how responsibilities are defined.

Moreover, actors engage in parallel platforms of global and club governance for development cooperation, sometimes in direct or indirect contestation with one another. Existing development cooperation platforms, such as the UN DCF and the GPEDC, work alongside new platforms, such as the UN High-level Political Forum and the G20 Development Group (Bracho 2021, Chapter 17; Lauria and Fumagalli 2019). Against this backdrop, we characterise the current policy field of development cooperation as being shaped by multiple sites of "contested cooperation".

\subsection{Development Cooperation as an Example of Contested Global Governance}

The policy field of development cooperation is central for addressing the twin challenges of the 2030 Agenda, but it is going through fundamental and dynamic changes that we characterise as "contested cooperation". Drawing on global governance research, we analyse contested cooperation for the specific case of development cooperation, but we also highlight broader implications for global governance challenges as such. "Global governance" can be understood as a normative concept for the search of more collective crossborder solutions, and therefore it relates closely to the twin challenges of the SDGs. Moreover, the main focus of global governance ${ }^{4}$ research lies in analysing structures and regulations supporting collective approaches beyond the hegemonic dominance of power politics.

Research on the current state of international cooperation speaks of "contested multilateralism" (Morse and Keohane 2014) and "contested global governance" (Cooper 2014; Zürn 2018a). There are two main forms of contestation: "politicisation of international authorities" (also called regime-shifting or institution-shifting) and "counter-institutionalisation" (also called regimecreation or institution-creation) (Morse and Keohane 2014; Zürn 2018a). Applying these concepts to development cooperation, actors can therefore either challenge existing international institutions by working through them, or create new international institutions that better address their needs, and thereby further serve the purpose "to influence or replace the old ones" (Zürn 2018 b, p. 12). ${ }^{5}$

According to Zürn (2018a), the politicisation of international institutions and counter-institutionalisation increase with the level and type of authority an institution has. The policy field of development cooperation-if narrowly defined as ODA only, for instance-typically involves little transfer of authority to international institutions and generally has lower salience in public debates than other policy areas such as trade or migration, for instance. Hence, we would expect moderate levels of contestation. However, if we assume a 
Table 1.1 Contested cooperation matrix: mapping the role of development cooperation for achieving the SDGs

\begin{tabular}{|c|c|c|c|}
\hline Contestation & & & \\
\hline \multirow[t]{4}{*}{ Cooperation } & & Institution-shifting & Institution-creation \\
\hline & $\begin{array}{l}\text { Established } \\
\text { cooperation }\end{array}$ & $\begin{array}{l}\text { 1. Updating } \\
\text { international institutions }\end{array}$ & $\begin{array}{l}\text { 2. Proliferating international } \\
\text { institutions }\end{array}$ \\
\hline & & $\begin{array}{l}\text { Examples: Updating SSC } \\
\text { definition }(B A P A+40), \\
\text { updating ODA reporting } \\
\text { system }\end{array}$ & $\begin{array}{l}\text { Examples: Creation of AIIB, } \\
N D B\end{array}$ \\
\hline & $\begin{array}{l}\text { New types of } \\
\text { cooperation }\end{array}$ & $\begin{array}{l}\text { 3. Collaborating in } \\
\text { international institutions } \\
\text { Examples: SDG Voluntary } \\
\text { National Reviews in } \\
\text { High-level Political Forum }\end{array}$ & $\begin{array}{l}\text { 4. Piloting collaboration } \\
\text { Examples: Voluntary } \\
\text { sustainability standards and } \\
\text { accompanying platform }\end{array}$ \\
\hline
\end{tabular}

Source Authors

broader definition of development cooperation that is closely integrated with other high-salience policy areas such as trade and investment, for instance, we could expect higher levels of contestation.

Therefore, the concept of contested cooperation describes the current development cooperation landscape that is shaped by ongoing processes of institution-shifting and institution-creation within established forms of development cooperation and new types of cooperation. As illustrated in Table 1.1, there are four main cases. In the first case, established types of cooperation and institution-shifting lead to actors "updating international institutions" (1). Examples for existing forms of cooperation are North-South cooperation, defined as ODA by the OECD-DAC, or longstanding types of SSC. With these established types of cooperation, OECD-DAC members, for example, politicise existing international institutions when they propose to change the reporting system of ODA towards accommodating their commercial interests. Correspondingly, providers of SSC might politicise the UN when they introduce new language on SSC in different international frameworks, such as the SDGs. Non-state actors can also contribute to institution-shifting in similar ways, either through influencing states to advocate on their behalf or by directly engaging. In the second case, existing forms of cooperation are combined with institution-creation, leading to what we call "proliferating international institutions" (2). Examples for contestation in the form of institution-creation are the NDB and the AIIB. Both incumbent and rising powers use counter-institutionalisation to challenge existing international institutions in development cooperation.

For cases three and four, we focus on new types of cooperation that are emerging in the SDG context, what we call "collaboration" for achieving 
the SDGs. The literature on defining collaboration typically describes collaboration as a qualitatively more ambitious type of cooperation (Emerson et al. 2012; Phillips et al. 2000; Thomson and Perry 2006; Wood and Gray 1991). We are therefore interested in seeing more profound and complex forms of collaboration among development actors as new types of "SDG collaboration" emerge. In the third case of Table 1.1, we expect that, coupled with contestation in the form of institution-shifting, these new types of cooperation can lead to "collaboration in international institutions" (3). Potential examples for this case could be South-North and North-North cooperation, multi-stakeholder partnerships, and other new and innovative forms of cooperation. The Voluntary National Reviews of the SDGs provide a specific example in which different countries showcase new types of cooperation within the UN.

The fourth case occurs when new types of cooperation are coupled with institution-creation, leading to "piloting cooperation" (4). Here, actors collaborate outside existing institutions and create new institutions to match their innovative types of cooperation. One illustrative example in this regard is the introduction of voluntary national sustainability standards, in which all types of countries (high-, medium-, and low-income) collaborate to define good social and environmental practices for an industry or product outside of existing international institutions in a flexible issue-specific format. This handbook illustrates the outcomes of contested cooperation and discusses the consequences of contested cooperation in the context of the SDGs by applying an actor-based perspective. Whether contested cooperation ultimately leads to improvements or failure in achieving the SDGs will depend on the specific decision-space of actors within a given site of contestation. Potential outcomes range from radical shifts to marginal changes in the form of institutional layering (Streeck and Thelen 2009) to complete gridlock (Hale et al. 2013).

In sum, this handbook contributes to an evolving academic and policy debate on governance challenges and their interaction with development cooperation. More specifically, the chapters in this book relate to debates on: the rise of ideas (norm generation and diffusion) in international relations (global) collective action, innovations on (global) solutions, global public and common goods, and the changing contexts of development cooperation within the context of global governance. All chapters apply varying understandings of development cooperation and the different concepts derived at in and beyond global governance research, yet they all showcase examples of contestation. Hence, these varied approaches to development cooperation, whether broadly or narrowly defined, can be used as exciting case studies for displaying various examples of contestation across different levels of authority transfer and salience. Ultimately, a better understanding of these sites of contested cooperation will contribute towards better coordination of competing narratives and norms in development cooperation to achieve the 2030 Agenda. 


\subsection{Structure of THE BoOK}

This handbook contributes to a better understanding of contestations that limit cooperation in the field of development cooperation. The chapters identify avenues for enhanced cooperation to achieve the 2030 Agenda. To address the twin challenges of the SDGs - the lack of coordination and contested responsibilities - we draw on multiple perspectives to capture how the policy field of development cooperation is changing in complex ways. We apply the concept of contested cooperation as a guiding concept: All contributions reflect on examples of contestation and cooperation and address how development cooperation can better contribute towards achieving the 2030 Agenda and the SDGs.

To answer the guiding question of this handbook-"How can different narratives and norms in development cooperation be reconciled to achieve the 2030 Agenda?" -it is organised into seven parts. The first part relates to governance challenges affecting the implementation of the 2030 Agenda more generally and within the context of specific SDGs. The chapters in this part outline context-specific needs for improving governance structures to achieve global public and common goods in different policy sectors and under consideration of different economic potentials. The second and third parts provide an overview on the evolution of different narratives and norms in the policy field of development cooperation by discussing the main changes in the policy field over the last several years and their consequences for measuring development cooperation.

The main change reflected on is the shift of the underlying rationale of development cooperation, from needs-based (alleviating poverty, providing basic services, etc.) towards more interest-based cooperation (political and economic interests), including the provision of global public and common goods (enlightened self-interest). This changing rationale of development cooperation also affects the implementation of the 2030 Agenda. The chapters of the second and third parts, therefore, contribute to a better understanding of the limits and opportunities for cooperation based on the evolution of different narratives and norms in development cooperation. Overall, the chapters in this part reflect on the trends driving the long-term transformation of development cooperation as well as the current shifts in the development narrative from various angles.

The fourth part focusses on the subject of norm competition, with specific reference to global institutional platforms for development cooperation (UN, G20, OECD, etc.) to provide a better understanding of persisting and new sites of contestation and their different contexts. In parallel to global governance becoming multi-polar, the development cooperation landscape has proliferated, offering multiple platforms for engagement. Each platform has a distinct history, mandate, and specific set of norms that it endorses. For decades, the OECD defined aid as ODA, whereas SSC had a distinct and different set of norms. With the recent rise of new global institutions and 
platforms, competition between norms has increased, as has the number of sites of contested cooperation within and outside of established formats of cooperation. The chapters in this part highlight different elements of the ongoing norm competition across the institutional landscape of development cooperation.

In contrast to parts one to four, which mostly focus on conceptual and scholarly debates, parts five to seven deepen policy debates. These parts are particularly relevant for practitioners and researchers who engage in debates on the quality of aid and the adoption of "aid effectiveness" principles. Both have received significant attention in development cooperation over the past decades but have lost momentum recently. Part five, for example, focusses on competing norms and narratives at the global and national levels. The chapters in this part discuss how norms and narratives can be better reconciled to enhance the quality of development cooperation towards achieving the 2030 Agenda by identifying pathways for connecting negotiating processes, exchanging knowledge, and harmonising strategies. In a similar vein, parts six and seven shed light on the conceptual and practical challenges for development cooperation as well as the contributions of South-South and triangular cooperation and non-state actors to the 2030 Agenda.

\section{Notes}

1. Over the past 20 years, various scholars have shifted the discussion on the diverse nature of collective goods to the transnational level. Kaul et al. (2016) define global public goods (GPGs) as commodities that enjoy global application in terms of use, cost, or both. Others use the term "global common good" to address goals or parameters that are relevant to a global community (Messner and Scholz 2018). Both the term global common good and GPGs, as concepts, have been influential when considering the political economy of collective action on a transnational level. Development cooperation plays a vital role in providing GPGs, and thereby international provision competes with the allocation of development cooperation resources on the national level.

2. Academic and policy literature has analysed different elements of these changes, such as the proliferation of development actors (Zimmermann and Smith 2011) and the diversification of development finance (Prizzon et al. 2017). Other researchers have investigated how the underlying rationale of the policy field itself has been changing, for instance through concepts such as "beyond aid" (Janus et al. 2015), "the end of ODA" (Severino and Ray 2009), or "the post-aid world" (Mawdsley et al. 2014).

3. Understood as encompassing "the totality of institutions, policies, norms, procedures and initiatives through which States and their citizens try to bring more predictability, stability and order to their responses to transnational challenges" (United Nations 2014, p. vi). In academic debates, the term "global governance" points to the exercise of authority across national borders.

4. Debates on the meaning of global governance, however, are also contested in several ways (Weiss and Wilkinson 2018). Scholars such as Acharya (2018), for example, disentangle the concept of global governance in relation to identified 
issue areas, areas within which intensified globalisation and the proliferation of collective action problems are central.

5. For this handbook, we do not prescribe an overarching definition of the term "institutions", given the large number of distinct rationalist or constructivist definitions of institutions. For the specific purpose of this introduction, however, we follow Duffield (2007, p. 8), who defines international institutions as "relatively stable sets of related constitutive, regulative, and procedural norms and rules that pertain to the international system, the actors in the system (including states as well as non-state entities), and their activities".

6. Cooperation occurs when participants agree on a shared problem that they try to solve through a division of labour, whereas collaboration refers to the process of working together to develop and sustain the solution of shared problems. Collaboration implies the sharing of risks, resources, responsibilities, and rewards, and it requires synchronised and coordinated activity (Camarihna-Matos and Afsarmanesh 2008). Cooperation and collaboration differ in terms of their depth of interaction, integration, commitment, and complexity, with cooperation falling at the low end of the continuum, and collaboration at the high end (Bryson et al. 2015). Collaboration is a process that evolves over time "in which autonomous actors interact through formal and informal negotiation, jointly creating rules and structures governing their relationships and ways to act or decide on the issues that brought them together; it is a process involving shared norms and mutually beneficial interactions" (Thomson and Perry 2006, p. 23). Thomson and Perry $(2006$, p. 23 ) argue that cooperation involves reciprocities and an exchange of resources that is not necessarily symmetrical and that "cooperation for a mutual goal moves this to collaboration".

\section{REFERENCES}

Acharya, A. (2018). The end of American world order. Hoboken, NJ: Wiley.

Ali, M. (2021). Monitoring and evaluation in South-South cooperation: The case of CPEC in Pakistan. In: Palgrave, this volume.

Allen, C., Metternicht, G., \& Wiedmann, T. (2018). Prioritising SDG targets: Assessing baselines, gaps and interlinkages. Sustainability Science, 14(2), 1-18.

Alonso, J. A., \& Glennie, J. (2015). What is development cooperation? https://www. un.org/en/ecosoc/newfunct/pdf15/2016_dcf_policy_brief_no.1.pdf.

Barbier, E. B., \& Burgess, J. C. (2019). Sustainable development goal indicators: Analyzing trade-offs and complementarities. World Development, 122, 295-305.

Beisheim, E., \& Liese, A. (Eds.). (2014). Transnational partnerships-Effectively providing for sustainable development? London: Palgrave Macmillan.

Bergamaschi, I., Moore, P., \& Tickner, A. B. (Eds.). (2017). South-South cooperation beyond the myths: Rising donors, new aid practices? London: Palgrave Macmillan.

Besharati, N., Rawhani, C., \& Rios, O. G. (2017). A monitoring and evaluation framework for South-South cooperation. https://saiia.org.za/wp-content/uploads/ 2017/05/saia_NeST-Working-Paper_20170515.pdf.

Bexell, M., \& Jönsson, K. (2017). Responsibility and the United Nations' Sustainable Development Goals. Forum for Development Studies, 44(1), 13-29.

Bhattacharya, D., Gonsior, V., \& Öhler, H. (2021). The implementation of the SDGs: The feasibility of using the GPEDC monitoring framework. In: Palgrave this volume. 
Bhattacharya, D., \& Llanos, A. O. (2016). Southern perspectives on the post-2015 international development agenda. London: Routledge.

Bodenstein, T., Faust, J., \& Furness, M. (2017). European Union development policy: Collective action in times of global transformation and domestic crisis. Development Policy Review, 35(4), 441-453.

Bowen, K. J., Cradock-Henry, N. A., Koch, F., Patterson, J., Häyhä, T., Vogt, J., \& Barbi, F. (2017). Implementing the "Sustainable Development Goals": Towards addressing three key governance challenges-collective action, trade-offs, and accountability. Current Opinion in Environmental Sustainability, 26, 90-96.

Bracho, G. (2021). Failing to share the burden: Traditional donors, Southern providers, and the twilight of the GPEDC and the post-war aid system. In: Palgrave, this volume.

Breuer, A., Janetschek, H., \& Malerba, D. (2019). Translating Sustainable Development Goal (SDG) interdependencies into policy advice. Sustainability, 11(7), 2092.

Bryson, J. M., Crosby, B. C., \& Stone, M. M. (2015). Designing and implementing cross-sector collaborations: Needed and challenging. Public Administration Review, 75(5), 647-663.

Burke, S., \& Rürup, B. L. (2019). Political thriller exposes the underbelly of global goals. Global Policy, 10(S1), 137.

Camarihna-Matos, L. M., \& Afsarmanesh, H. (2008). Concept of collaboration. In D. G. Putnik \& M. M. Cunha (Eds.), Encyclopedia of networked and virtual organizations (pp. 311-315). Hershey, NY: IGI Global.

Chan, S., Iacobuta, G., \& Haegele, R. (2021). Maximising goal coherence in sustainable and climate-resilient development? Polycentricity and coordination in governance. In: Palgrave this volume.

Chaturvedi, S. (2016). The development compact: A theoretical construct for SouthSouth cooperation. International Studies, 53(1), 15-43.

Chaturvedi, S., Fues, T., \& Sidiropoulos, E. (2012). Development cooperation and emerging powers: New partners or old patterns?. London: Zed Books.

Cooper, A. F. (2014). The G20 and contested global governance: BRICS, middle powers and small states. Caribbean Journal of International Relations and Diplomacy, 2(3), 87-109.

Cooper, N., \& French, D. (2018). SDG 17: Partnerships for the goals-Cooperation within the context of a voluntarist framework. In D. French \& L. J. Kotzé (Eds.), Sustainable Development Goals: Law, theory and implementation (pp. 271-304). Cheltenham: Edward Elgar Publishing.

DiMaggio, P. J., \& Powell, W. W. (1983). The iron cage revisited: Institutional isomorphism and collective rationality in organizational fields. American Sociological Review, 48(2), 147-160.

Duffield, J. (2007). What are international institutions? International Studies Review, $9(1), 1-22$.

Emerson, K., Nabatchi, T., \& Balogh, S. (2012). An integrative framework for collaborative governance. Journal of Public Administration Research and Theory, 22(1), $1-29$.

Fejerskov, A. M. (2016). Understanding the nature of change: How institutional perspectives can inform contemporary studies of development cooperation. Third World Quarterly, 37(12), 2176-2191. 
Fejerskov, A. M., Lundsgaarde, E., \& Cold-Ravnkilde, S. (2017). Recasting the "new actors in development" research agenda. The European Journal of Development Research, 29(5), 1070-1085.

Fiddian-Qasmiyeh, E., \& Daley, P. (2019a). Introduction. Conceptualising the Global South and South-South encounters. In E. Fiddian-Qasmiyeh \& P. Daley (Eds.), Routledge handbook of South-South relations (pp. 1-28). London and New York, NY: Routledge.

Fiddian-Qasmiyeh, E., \& Daley, P. (2019b). Routledge handbook of South-South relations. London and New York, NY: Routledge.

Florini, A. (2018). Professionalizing cross-sector collaboration to implement the SDGs. In R. M. Desai, H. Kato, H. Kharas, \& J. W. McArthur (Eds.), From summits to solutions: Innovations in implementing the Sustainable Development Goals (pp. 106-125). Washington, DC: The Brookings Institution.

Fourie, E., Nauta, W., \& Mawdsley, E. (2019). Introduction. In E. Mawdsley, E. Fourie, \& W. Nauta (Eds.), Researching South-South development cooperation: The politics of knowledge production (pp. 1-11). London and New York, NY: Routledge.

Fukuda-Parr, S., \& McNeill, D. (2019). Knowledge and politics in setting and measuring the SDGs: Introduction to special issue. Global Policy, 10(S1), 5-15.

Government of India. (2018, June 5). IBSA Declaration on South-South Cooperation. https://www.mea.gov.in/bilateral-documents.htm?dtl/29955/IBSA_Declara tion_on_SouthSouth_Cooperation.

Gray, K., \& Gills, B. K. (Eds.). (2018). Rising powers and South-South cooperation. London: Routledge.

Hale, T., Held, D., \& Young, K. (2013). Gridlock: Why global cooperation is failing when we need it most. Cambridge: Polity Press.

Hansen, A., \& Wethal, U. (Eds.). (2015). Emerging economies and challenges to sustainability: Theories, strategies, local realities. London: Routledge.

Janus, H., Klingebiel, S., \& Paulo, S. (2015). Beyond aid: A conceptual perspective on the transformation of development cooperation. Journal of International Development, 27(2), 155-169.

Janus, H., \& Tang, L. (2021). Conceptualising ideational convergence of China and OECD donors: Coalition magnets in development cooperation. In: Palgrave this volume.

Kapto, S. (2019). Layers of politics and power struggles in the SDG indicators process. Global Policy, 10(S1), 134-136.

Kaul, I. (2016). Global public goods. Cheltenham: Edward Elgar.

Kaul, I., Blondin, D., \& Nahtigal, N. (2016). Understanding global public goods: Where we stand and where to next. In I. Kaul (Ed.), Global public goods (pp. xiiixcii). Cheltenham: Edward Elgar Publishing.

Kaul, I. (2018). Conceptualizing global public policy: A global public good perspective. In D. Stone \& K. Moloney (Eds.), The Oxford handbook of global policy and transnational administration. Oxford: Oxford University Press.

Keijzer, N. (2016). Open data on a closed shop? Assessing the potential of transparency initiatives with a focus on efforts to strengthen capacity development support. Development Policy Review, 34(1), 83-100.

Kharas, H., \& Rogerson, A. (2017). Global development trends and challenges: Horizon 2025 revisited. https://www.odi.org/sites/odi.org.uk/files/resource-doc uments/11873.pdf. 
Klingebiel, S., Mahn, T., \& Negre, M. (Eds.). (2016). The fragmentation of aid: Concepts, measurements and implications for development cooperation. London: Palgrave Macmillan.

Kragelund, P. (2019). South-South development. London: Routledge.

Lauria, V., \& Fumagalli, C. (2019). BRICS, the Southern model, and the evolving landscape of development assistance: Toward a new taxonomy. Public Administration and Development (online version of record before inclusion in an issue). https://onlinelibrary.wiley.com/doi/full/10.1002/pad.1851.

Le Blanc, D. (2015). Towards integration at last? The Sustainable Development Goals as a network of targets. Sustainable Development, 23(3), 176-187.

Mawdsley, E. (2019). South-South cooperation 3.0? Managing the consequences of success in the decade ahead. Oxford Development Studies, 47(3), 1-16.

Mawdsley, E., Fourie, E., \& Nauta, W. (2019). Researching South-South development cooperation: The politics of knowledge production. London: Routledge.

Mawdsley, E., Murray, W. E., Overton, J., Scheyvens, R., \& Banks, G. (2018). Exporting stimulus and "shared prosperity": Reinventing foreign aid for a retroliberal era. Development Policy Review, 36(S1), O25-O43.

Mawdsley, E., Savage, L., \& Kim, S. M. (2014). A “post-aid world”? Paradigm shift in foreign aid and development cooperation at the 2011 Busan High Level Forum. The Geographical Journal, 180(1), 27-38.

McNeill, D. (2019). The contested discourse of sustainable agriculture. Global Policy, $10(\mathrm{~S} 1), 16-27$.

Mello e Souza, A. (2021). Building a global development cooperation regime: Necessary but failed efforts. In: Palgrave this volume.

Messner, D., \& Scholz, I. (2018). Globale Gemeinwohlorientierung als Fluchtpunkt internationaler Kooperation für nachhaltige Entwicklung - Ein Perspektivwechsel. Zeitschrift Für Außen- Und Sicherheitspolitik, 11(4), 561-572.

Mitchell, I. (2021). Measuring development cooperation and the quality of aid. In: Palgrave this volume.

Morse, J. C., \& Keohane, R. O. (2014). Contested multilateralism. The Review of International Organizations, 9(4), 385-412.

Mthembu, P. (2018). Conceptual framework and the importance of consistent definitions. In P. Mthembu (Ed.), China and India's development cooperation in Africa: The rise of Southern powers (pp. 15-27). Cham: Springer International Publishing.

Nilsson, M., Griggs, D., \& Visbeck, M. (2016). Policy: Map the interactions between Sustainable Development Goals. Nature News, 534(7607), 320.

Olson, M. (2009). The logic of collective action (p. 124). Cambridge, MA: Harvard University Press.

Organisation for Economic Co-operation and Development. (2018). Development cooperation report 2018: Joining forces to leave no one behind. Paris: OECD Publishing.

Paulo, S., \& Klingebiel, S. (2016). New approaches to development cooperation in middle-income countries-brokering collective action for global sustainable development (Discussion Paper 8/2016). Bonn: German Development Institute/Deutsches Institut für Entwicklungspolitik (DIE).

Pauw, P., Bauer, S., Richerzhagen, C., Brandi, C., \& Schmole, H. (2015). Different perspectives on differentiated responsibilities (Discussion Paper 6/2014). Bonn: German Development Institute/Deutsches Institut für Entwicklungspolitik (DIE). 
Pérez-Pineda, J. A., \& Wehrmann, D. (2021). Partnerships with the private sector: Success factors and levels of engagement in development cooperation. In: Palgrave this volume.

Phillips, N., Lawrence, T. B., \& Hardy, C. (2000). Inter-organizational collaboration and the dynamics of institutional fields. Journal of Management Studies, 37(1), 2343.

Prizzon, A., Greenhill, R., \& Mustapha, S. (2017). An "age of choice" for external development finance? Evidence from country case studies. Development Policy Review, 35(S1), O29-O45.

Roberts, K. M. (2018). Populism and political representation. In C. Lancaster \& N. van de Walle (Eds.), The Oxford handbook of the politics of development. Oxford: Oxford University Press.

Rudolph, A. (2017). The concept of SDG-sensitive development cooperation: Implications for OECD-DAC members (Discussion Paper 1/2017). Bonn: German Development Institute/Deutsches Institut für Entwicklungspolitik (DIE).

Scott, W. R. (2013). Institutions and organizations: Ideas, interests, and identities. Los Angeles, CA: Sage.

Severino, J.-M., \& Ray, O. (2009). The end of ODA: Death and rebirth of a global public policy (Working Paper No. 167). Washington, DC: Center for Global Development.

Streeck, W., \& Thelen, K. (2009). Institutional change in advanced political economies. In B. Hancké (Ed.), Debating varieties of capitalism: A reader (pp. 95131). Oxford: Oxford University Press.

Thomson, A. M., \& Perry, J. L. (2006). Collaboration processes: Inside the black box. Public Administration Review, 66(S1), 20-32.

Tjosvold, D. (1984). Cooperation theory and organizations. Human Relations, 37(9), 743-767.

Tosun, J., \& Leininger, J. (2017). Governing the interlinkages between the Sustainable Development Goals: Approaches to attain policy integration. Global Challenges, 1(9), 1700036.

TWI2050-The World in 2050 (2018). Transformations to achieve the Sustainable Development Goals. Laxenburg, Austria: International Institute for Applied Systems Analysis.

Uchenna, E., \& Simplice, A. (Eds.). (2018). Financing sustainable development in Africa. London: Palgrave Macmillan.

United Nations. (2014). Global governance and global rules for development in the post-2015 era. Policy Note. Committee for Development Policy. http://www.un. org/en/development/desa/policy/cdp/cdp_publications/2014cdppolicynote.pdf.

United Nations Department of Economic and Social Affairs. (2018). Financing for development: Progress and prospects 2018. Report of the Interagency Task Force on Financing for Development. https://www.un.org/development/desa/publicati ons/financing-for-development-progress-and-prospects-2018.html.

Wang, H. (2015). The Asian Infrastructure Investment Bank: A New Bretton Woods moment? A total Chinese triumph? (CIGI Policy Brief No. 59). https://www.files. ethz.ch/isn/190852/policy_brief_no_59.pdf.

Wang, H. (2019). The New Development Bank and the Asian Infrastructure Investment Bank: China's ambiguous approach to global financial governance. Development and Change, 50(1), 221-244. 
Wehrmann, D. (2018). Incentivising and regulating multi-actor partnerships and private-sector engagement in development cooperation (Discussion Paper 21/2018). Bonn: German Development Institute/ Deutsches Institut für Entwicklungspolitik (DIE).

Weiss, T. G., \& Wilkinson, R. (Eds.). (2018). International organization and global governance (2nd ed.). London: Routledge.

Wood, D. J., \& Gray, B. (1991). Toward a comprehensive theory of collaboration. The Journal of Applied Behavioral Science, 27(2), 139-162.

World Bank (2018). Information and communications for development 2018: Data-driven development. https://openknowledge.worldbank.org/handle/10986/ 30437.

Zimmermann, F., \& Smith, K. (2011). More actors, more money, more ideas for international development co-operation. Journal of International Development, 23(5), $722-738$.

Zürn, M. (2018a). Contested global governance. Global. Policy, 9(1), 138-145.

Zürn, M. (2018b). A theory of global governance: Authority, legitimacy, and contestation. Oxford: Oxford University Press.

Open Access This chapter is licensed under the terms of the Creative Commons Attribution 4.0 International License (http://creativecommons.org/licenses/by/4.0/), which permits use, sharing, adaptation, distribution and reproduction in any medium or format, as long as you give appropriate credit to the original author(s) and the source, provide a link to the Creative Commons license and indicate if changes were made.

The images or other third party material in this chapter are included in the chapter's Creative Commons license, unless indicated otherwise in a credit line to the material. If material is not included in the chapter's Creative Commons license and your intended use is not permitted by statutory regulation or exceeds the permitted use, you will need to obtain permission directly from the copyright holder.

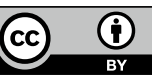

